\title{
Improving maternal and fetal pregnancy outcomes: in memoriam, Doctor Frederick Morfaw (1980-2020)
}

Lawrence Mbuagbaw ${ }^{1,2,3^{*}}$ and Lehana Thabane $e^{1,2,4,5,6}$

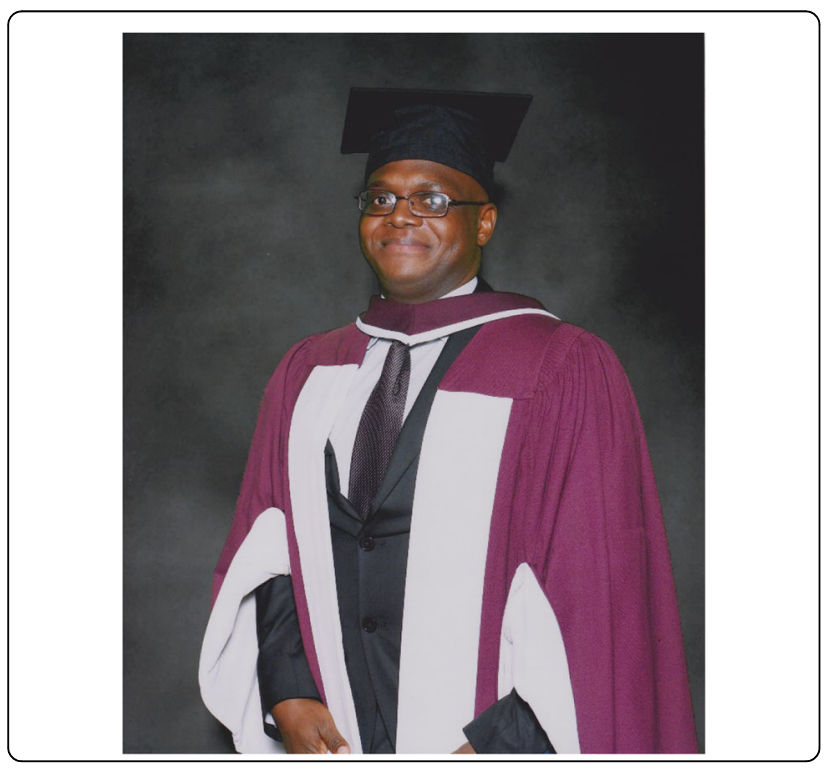

We are disheartened by the sudden passing of Dr. Frederick Morfaw. He was an avid advocate of mother and child health research and made important contributions to male partner participation in vertical transmission of HIV programs. Before his untimely death on Monday, June 15, 2020, he had just completed a research fellowship in perinatal clinical epidemiology with McMaster's Department of Obstetrics and Gynecology. Born in Limbe, South West

\footnotetext{
* Correspondence: mbuagblc@mcmaster.ca

'Department of Health Research Methods, Evidence and Impact, McMaster University, Hamilton, Ontario, Canada

${ }^{2}$ Biostatistics Unit, Father Sean O'Sullivan Research Centre, St Joseph's

Healthcare-Hamilton, 50 Charlton Avenue East, 3rd Floor Martha Wing, Room H321, Hamilton, Ontario L8N 4A6, Canada

Full list of author information is available at the end of the article
}

Region, Cameroon, on January 5, 1980, he pursued a life of academic excellence. He completed his secondary and high school at Sacred Heart College, Bamenda, and then trained as a Medical Doctor in the Faculty of Medicine and Biomedical Sciences, University of Yaoundé 1 from 1998 to 2005 graduating with a Doctor of Medicine (MD) degree. He then completed a Master of Science in Public Health Research at the University of Edinburgh in 2008. Following his return from the UK, he completed his specialization in Obstetrics and Gynecology in 2013 with honors at the University of Yaoundé I. He worked as a consultant gynecologist/obstetrician for 5 years at the Bamenda Regional Hospital. During this specialization, he completed an international postdoctoral fellowship with the Canadian HIV Trials Network in 2012. His accolades include the Mandela Washington African Leadership Initiative award (2015); the Drug Safety and Effectiveness Cross-Disciplinary Training Program Award (2018); the Ontario Drug Policy Research Network Student Training Program Award (2019); and the David L. Sackett Scholarship (2019)

\section{Contributions to science and to mother-and-child health}

Frederick was a reviewer and associate editor for Pilot and Feasibility Studies since 2018 and personally oversaw the review and publication of several manuscripts, providing insight into how best to design, conduct, and report pilot studies in mother and child health. He completed important research on male partner involvement in prevention programs of mother to child transmission of HIV, highlighting the importance of having partners support their spouses morally and financially, in order to enhance the uptake of prevention programs [1]. His work led to the

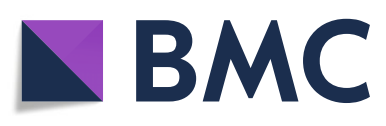

C C The Author(s). 2020 Open Access This article is licensed under a Creative Commons Attribution 4.0 International License, which permits use, sharing, adaptation, distribution and reproduction in any medium or format, as long as you give appropriate credit to the original author(s) and the source, provide a link to the Creative Commons licence, and indicate if changes were made. The images or other third party material in this article are included in the article's Creative Commons licence, unless indicated otherwise in a credit line to the material. If material is not included in the article's Creative Commons licence and your intended use is not permitted by statutory regulation or exceeds the permitted use, you will need to obtain permission directly from the copyright holder. To view a copy of this licence, visit http://creativecommons.org/licenses/by/4.0/ The Creative Commons Public Domain Dedication waiver (http://creativecommons.org/publicdomain/zero/1.0/) applies to the data made available in this article, unless otherwise stated in a credit line to the data. 
development of a scale that can be used to measure male partner participation. He also conducted research highlighting the benefits of misoprostol in preventing post partum hemorrhage ( $\mathrm{PPH})$ [2], which is responsible for one maternal death in low-income countries every $4 \mathrm{~min}$ [3].

Frederick was dedicated to mentoring junior colleagues. Numerous colleagues in Cameroon and Canada can attest to his highly supportive and collaborative approach to research. He contributed to building capacity in HIV research in Africa through workshops and also helped outline guidance for early career health researchers $[4,5]$. He was part of a network of early career researchers supported by the Canadian HIV Trials Network that played an important role in building HIV research capacity on the African continent [6].

Frederick is survived by his wife, Laura, two daughters, Vanessa and Ricka, and one son, Prince Henry. He will be remembered for his cheerful hearty laughter and jovial disposition. In addition to his academic achievements, Frederick excelled in gymnastics as a child, played soccer, ping-pong, and took pleasure in traveling. We honor his life and legacy by continuing his research. Rest in peace, Frederick, our brother, friend, colleague, and mentor.

\section{Acknowledgements}

None

\section{Authors' contributions}

LM and LT drafted the manuscript. All authors reviewed and edited versions of the manuscript for content. All authors approved the final version of the manuscript.

Funding

No funding was used for this study.

Availability of data and materials

Not applicable

Ethics approval and consent to participate

Not applicable

\section{Consent for publication}

Not applicable

\section{Competing interests}

The authors declare that they have no competing interests.

\section{Author details}

'Department of Health Research Methods, Evidence and Impact, McMaster University, Hamilton, Ontario, Canada. ${ }^{2}$ Biostatistics Unit, Father Sean O'Sullivan Research Centre, St Joseph's Healthcare-Hamilton, 50 Charlton Avenue East, 3rd Floor Martha Wing, Room H321, Hamilton, Ontario L8N 4A6, Canada. ${ }^{3}$ Centre for the Development of Best Practices in Health, Yaoundé, Cameroon. ${ }^{4}$ Departments of Pediatrics and Anesthesia, McMaster University, Hamilton, Ontario, Canada. ${ }^{5}$ Centre for Evaluation of Medicine, St Joseph's Healthcare-Hamilton, Hamilton, Ontario, Canada. ${ }^{6}$ Population Health Research Institute, Hamilton Health Sciences, Hamilton, Ontario, Canada.

Published online: 08 September 2020

\section{References}

1. Morfaw F, Mbuagbaw L, Thabane L, Rodrigues C, Wunderlich AP, Nana P, Kunda J. Male involvement in prevention programs of mother to child transmission of $\mathrm{HIV}$ : a systematic review to identify barriers and facilitators. Syst Rev. 2013;2:5.
2. Morfaw F, Fundoh M, Pisoh C, Ayaba B, Mbuagbaw L, Anderson LN, Thabane L. Misoprostol as an adjunct to oxytocin can reduce postpartumhaemorrhage: a propensity score-matched retrospective chart review in Bamenda-Cameroon, 2015-2016. BMC Pregnancy Childbirth. 2019;19:257.

3. Chong YS, Su LL. Misoprostol for preventing PPH: some lessons learned. Lancet. 2006;368:1216-8.

4. Mbuagbaw L, Slogrove A, Sas J, Kunda J, Morfaw F, Mukonzo J, Thabane L. CIHR Canadian HIV trials network HIV workshop: ethical research through community participation and strengthening scientific validity. Pan Afr Med J. 2014;19:44.

5. Mbuagbaw L, Morfaw F, Kunda JE, Mukonzo JK, Kastner J, Zhang S, Kokolo $M$, Thabane L. Tips for charting the course of a successful health research career. J Multidiscip Healthc. 2013;6:163-8.

6. Mbuagbaw L, Slogrove AL, Sas J, Lengwe Kunda J, Morfaw F, Mukonzo JK Cao W, Ngomba-Kadima G, Zunza M, Ongolo-Zogo P, et al. Output from the CIHR Canadian HIV Trials Network international postdoctoral fellowship for capacity building in HIV clinical trials. HIV AIDS (Auckl). 2018;10:151-5.

\section{Publisher's Note}

Springer Nature remains neutral with regard to jurisdictional claims in published maps and institutional affiliations.

\section{Ready to submit your research? Choose BMC and benefit from:}

- fast, convenient online submission

- thorough peer review by experienced researchers in your field

- rapid publication on acceptance

- support for research data, including large and complex data types

- gold Open Access which fosters wider collaboration and increased citations

- maximum visibility for your research: over $100 \mathrm{M}$ website views per year

At BMC, research is always in progress.

Learn more biomedcentral.com/submissions 